Open Access

\title{
Weak signal detecting of industry convergence using information of products and services of global listed companies - focusing on growth engine industry in South Korea -
}

Lee-Nam Kwon ${ }^{1}$, Jun-Hwan Park', Yeong-Ho Moon ${ }^{1}$, Bangrae Lee ${ }^{1}$, YoungHo Shin ${ }^{1}$ and Young-Kuk Kim² ${ }^{2 *}$

\author{
*Correspondence: ykim@cnu.ac.kr \\ ${ }^{2}$ Department Of Computer Science \\ and Engineering, Chungnam \\ National University, Seoul, Korea \\ Full list of author information is \\ available at the end of the article
}

\begin{abstract}
The [World Economic Forum 2016, https://www.weforum.org/events/world-economicforum-annual-meeting-2016. Accessed 5 Aug 2017] predicted that the world would face the Fourth Industrial Revolution which means innovative changes through convergence of cutting-edge information and communications technologies (ICTs) such as artificial intelligence, loT, big data and cloud computing with conventional industries. It was forecasted that such innovation would take place across all industries and services. In particular, the Fourth Industrial Revolution has paid attention to changes in conventional traditional industries. The weak signal analysis is a method which can detect the sign of future changes at an early stage. A weak signal is defined as an advanced indicator in such changes. Therefore, its search and monitoring can be an early warning on threat and great opportunity to be prepared. To overcome the limitation of future prediction which is mostly dependent upon an expert group's intuitive judgment, this study attempted to investigate the weak signal of convergence among industries, using knowledge structure based approaches. As new products and services can lead to convergence between industries, research data has gathered information on the products and services of global listed companies which have been established for the past 11 years. For comparative analysis, they were grouped every 5 years, and product and service trends were compared. And we detected weak signals of convergence with different industries and noticed the changes of existing industries. Historically, the convergence of industries is mainly discussed in relation to science and technology-led industries, so the industrial field that has been studied has chosen Korea's growth engine industries, a high-tech science and technology industries.
\end{abstract}

Keywords: Sharing economy, Global listed companies, Convergence trend, Weak signal, Growth engine industry

\section{Introduction}

Today, businesses are exposed to rapidly changing business environments. Under these circumstances, it is very difficult for them to launch and lead new business just by responding to such changes. Therefore, businesses have pursued open innovation by

(c) The Author(s). 2018 Open Access This article is distributed under the terms of the Creative Commons Attribution 4.0 International License (http://creativecommons.org/licenses/by/4.0/), which permits unrestricted use, distribution, and reproduction in any medium, provided you give appropriate credit to the original author(s) and the source, provide a link to the Creative Commons license, and indicate if changes were made. 
monitoring and converging external knowledge to stay competitive in global market. For this, there have been a lot of studies. Many studies such as "Application of Open Innovation to Social Business (Svirina et al., 2016)", "Effects of Service Innovation on Government Support System (Si-jeoung et al., 2016)", "A Study on the development of new Innovation Diagram based on three elements - Technology - Business Model (BM) - Market (JinHyo et al., 2016)", and "Analysis of Core Competency Enhancing Relationship between Innovation Performances and TQM Implementation (Maha, 2016)" have insisted that businesses need to keep monitoring diverse internal and external environments and promoting innovation.

The 2016 World Economic Forum in Davos, experts predicted continued low growth of world economy, increase in the risk of Chinese economy, low oil price, decrease in global productivity and acceleration of industrial competition. As a way to overcome such problems, they suggested that businesses need to well understand the Fourth Industrial Revolution and get fully prepared. 2016 was the year when 'Sharing Economy', one of the core businesses of the Fourth Industrial Revolution, had a significant influence on industries. This trend would be called "uberization". In fact, it brought a sensation to conventional industries while being defined as a new economic term.

This new term originated from the word 'uber'. It refers to direct transaction between the consumer and supplier through the Internet without any broker. Recently, it has rapidly spread across industries such as lodging industry, finance, law and medicine as well as transportation. In 2015, the Wall Street Journal predicted that 'uberization' would be available in all services.

It's forecasted that diverse ICT platform-based services and business models would increase, and industrial competition would become more intense. In addition, the importance of conventional industries has been re-illuminated. To understand these changes which have spread across industries through convergence with conventional industries based ICT, it is necessary to examine 'weak signal', a sign of future changes on industrial products and services.

A weak signal is an advanced indicator on certain phenomena. Monitoring this is essential in assessing timely warning and origin of uncertainty (Sandro et al., 2012). This study targets to suggest implications after analyzing business service trends and investigating a weak signal on convergence services with data on the products and services of global listed companies from 2005 to 2015.

\section{Literature review}

\section{1. Weak signals}

Ansoff (1975) introduced a concept called weak signals for preventing long-rangeplanning or strategic-planning problems, and categorized information into two groups: strong signals and weak signals. Weak signals can become clearer and strengthen over time to become strong signals or they might vanish.

Godet (1994) defined it as a sign of a big change near the future even though it is hard to see it at present. In other words, it is deemed as one of the methods to analyze uncertain future. Hiltunen (2008) suggested a 3D spatial model comprised of signal, issue and interpretation as a sign of future changes. 'Signal' refers to the number of signals or visibility while 'issue' represents the number of issues. Lastly, 'interpretation' 
means a degree of recognition of future signal by information users. As the number of signals and issues increases in a 3D space, and such signal has a bigger influence on information users, a weak signal moves to a strong signal Fig. 1.

Coffman (1997) stated the 7 different characteristics of 'weak signal' and explained it specifically. He insisted that they bring changes in political, economic, technical and social thoughts and inventions. Kuosa (2010) said that a weak signal should bring significant effects in the future, or it would probably end up as a meaningless chatter (cf. Table 1). In fact, it is a critical matter to separate the weak signal from the meaningless chatter.

Coffman (1997) and Brown (2007) applied a concept of 'weak signal' to the analysis of business environments in their studies. Kaivo-oja (2012) studied integration with corporate knowledge management theory. In addition, Sandro et al. (2012) added weak signal analysis to the level 6 in a business foresight analysis framework.

In fact, there have been many other studies on weak signal analysis in diverse fields such as R\&D environment change monitoring \& future studies, international security, politics and communication studies (Sun-Hi et al., 2009). The approach to detect weak signals is mainly based on expert discussions, Delphi methods, and intuitive judgment by experts, which is time consuming and costly.

To solve these problems, researches using a knowledge structure based approach for clustering have been started (Thorleuchter and Van den Poel, 2015). There are qualitative and quantitative approaches to the analysis of knowledge structures. The qualitative approach has the advantage that it is easier to grasp the knowledge structure as a way to obtain opinions from the research field to a small number of experts, but there are disadvantages such as bias or subjective errors of the experts (Law \& Whittaker, 1992). Social network analysis, which is widely used as an analysis method of knowledge structure, is an analytical method for constructing a keyword network using keywords as objects, analyzing them quantitatively, and grasping the relationship between keywords. (Newman and Girvan, 2004; Scott, 1991). Key indicator of social network analysis include co-occurence, centrality, and clustering analysis of keywords.

Tabatabaei (2011) considered environmental scanning of Web as the main way to detect emerging weak signals in the digital media field, and applied web mining, text

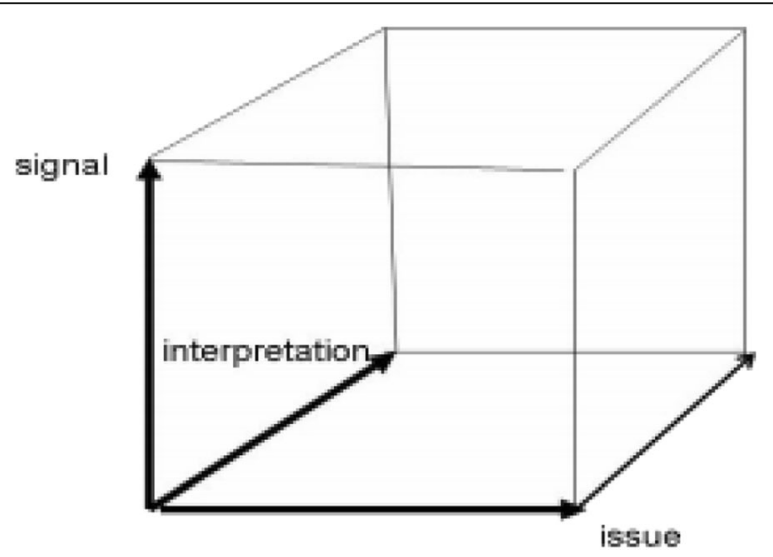

Fig. 1 Hiltunen's Three-dimensional Future Sign 
Table 1 Signals: Probabilities and Effects (Kuosa, 2010, p. 43)

\begin{tabular}{lll}
\hline & Small Effect & Big Effect \\
\hline Small probability of coming true & Meaningless chatter & Weak signal \\
Big probability of coming true & Original trend & Megatrend \\
\hline
\end{tabular}

mining, and document clustering to analyze. Janghyeok (2012) studied Internet-based environmental scanning combined with weak signal analysis and used keyword-based text mining using Web news. In contrast to the knowledge structure based approach, research using a semantic clustering approach focusing on the meaning of text has also been conducted (Thorleuchter and Van den Poel, 2015).

\section{2. Industry convergence}

The convergence started from the research centered on technology convergence, but it is gradually expanding to the study of science, value, market, and industry convergence.

In general, the method for analyzing technology convergence is to analyze the citation information of patents (Trajtenberg et al., 1997) or measure the degree of convergence of technology using ipc co-classification information of patent (Curran \& Leker, 2011).

Most scholars have focused on the media, information technology or electronics industry to study industrial convergence, primarily because it relates to high-level industries that are centered on science and technology (Schnaars et al., 2008).

According to Curran and Leker (2011), convergence is a sequential process, and when science, technology, and market converge, it evolves sequentially to the stage of industry convergence. In addition, industry convergence can be achieved through either a new business model or a new product / service.

In this study, we analyzed the trend of industrial convergence using information of products and services of global companies.

\section{3. Growth engine industry}

Korea's growth engine industry refers to core technologies or products/services which would create new market from a long-term perspective, evolve into new industry and make a big contribution to the improvement of added values and job creation if it is discovered and promoted by the government or national strategy (Seok-in et al., 2014). Under this policy, Korean government has strategically chosen future growth engine industry for economic growth and job creation since April 2015. In fact, such strategic industry growth policy has been the mainstream around the globe. It includes the US government's innovation strategies (the White House, USA, 2011), Japan's Industrial Structure Vision (METI Japan, 2010) and EU's core implementation technology selection \& promotion (EU, 2010). The 10 Biggest Startup Opportunities $2016^{1}$ published by CIO Magazine are also considerably matched with the growth engine industries named by Korean government.

According to previous studies on the number of new global businesses by Korea's growth engine industry, even though the number of business startups was declining by 
$12 \%$ from the prior year (2013), the number of businesses from growth engine industry has increased in the Group of 7 (G7) (Lee-Nam et al., 2016).

\section{Analysis method}

The methodology of this study is based on a knowledge structure based approach to search for the weak signals of inter-industry convergence. However, it is differentiated method by using keyword network analysis, betweeness centrality for convergence measurement, and minimum spanning tree (MST).

We use keyword network analysis in order to distinguish weak signal and meaningless chatter, and to express related product and service keywords in network, and applied MST to visualize which links in the product and service nodes are important and to show only the backbone of the graph.

This study analyzed the products and services of the global listed companies which have been established for the past 11 years for the purpose of discovering a weak signal and service trends which have been linked with diverse industries in convergence with conventional services.

First, this study attempted to detect intra- or inter-industry service trends and changes by analyzing a keyword network on the business types and products \& services of the global listed companies. For this, they were divided into two groups (2005-2010, 2011-2015) by the year of establishment and comparatively analyzed. For analysis data, ORBIS database, a business information database (approx. 154 million items) of the digital publisher 'Bureau Van Dijk (https://orbis.bvdinfo.com)' was used.

First of all, data on the business types and products \& services of 16,151 global listed companies (excluding 177 firms in which business code is missing) from 2005 to 2015 were extracted. Then, 5626 listed companies in growth engine industry were selected. For target industry, Korea's growth engine industry was chosen. Each industrial sector can be classified under the Korea Standard Industrial Classification (KSIC).

In the ORBIS, U.S. SIC is used for business code. Since the information which can map both U.S SIC and KSIC is provided, the KSIC code which belongs to growth engine industry can be mapped by the major group (2-digit) of the SIC code. In addition, 'products and services' provided by the ORBIS are mostly the items collected by the analyst or data provider. Therefore, general and simple data are provided. Because data are usually available in phrase, they are good for the analysis of a keyword network. To figure out convergence with other services (or products) under the same industry, a keyword network analysis method was used, and products \& services and inter-service connectivity were set with 'node' and 'link' respectively.

The co-occurrence matrix between phrases (keywords) which represent products \& services shows the number of the businesses in which different keywords occur at the same time. Therefore, increase in this value means that many companies provide products and services. The actual data format is 'weighted edge list' just like 'source-targetweight'. Here, 'source' and 'target' represent 'products' and 'services' each while 'weight' refers to the value of the co-occurrence matrix. In reality, inverse values were used. An inverse number was used for weight to sort core links in the MST.

The graph consists of node and edge. In the said co-occurrence matrix, the keyword of 'source' and 'target' in 'source-target-weight' form is node while the line which 
connects source and target is 'edge'. Lastly, the weighted value of the edge is 'weight'. Even though there would be diverse ways to visualize the graph, the force-directed placement (FDP) is a technique to visualize all nodes and links. However, this kind of visualization technique is not preferred because its visibility drops when the number of nodes and edges increases. To visualize a big graph having a lot of nodes and edges, it is preferred to express a graph in backbone. Among these methodologies, MST is basically used.

MST is a methodology to visualize the edges which minimizes the weighted sum of all nodes on a network. For example, let's say the undirected graph $G=(V, E)$. Here, ' $V$ ' is a set of vertex (another name of a node) while 'E' represents a set of edges. The weighted value of random edge ( $u, v)$ in ' $E$ ' is taken as ' $w(u, v)$ ', and sum of total weighted values linking all vertexes is stated as ' $w(T)$ '. Then, the following equation appears:

$$
w(T)=\sum_{(u, v) \in T} w(u, v)
$$

In the MST problem, it is essential to discover the power set (' $\mathrm{T}$ ') of the edge set which minimizes the equation ' $\mathrm{w}(\mathrm{T})$ ' Fig. 2. Consequently, the group comprised of the power set 'T' and node set ' $\mathrm{V}$ ' is stated as follows $(G$ ' $=(\mathrm{V}, \mathrm{T}))$ Cormen et al. (2001):

Meanwhile, the MST algorithm chooses edges which minimize the weighted value of path. Therefore, the value with lower edge is selected. In co-occurrence matrix used in this study, however, the one with higher weighted value is a more important edge. To select more important edges, hence, this study took reverse weighted values.

In basic MST algorithm, a node size is not considered. From the perspective of information analysis, however, it is useful to visualize what keywords are important. Therefore, this study attempted to differentiate node sizes and express them in the MST figure. For the standards to differentiate a node size, the importance of a node's mediating role in a whole network was examined. In other words, it was interpreted that if

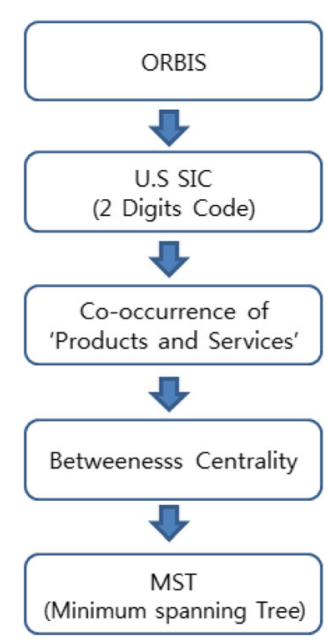

Download information on products and services from global listed companies for 2005 2015 (based on U.S SIC)

Mapping with KSIC and U.S SIC major group (2 digits) corresponding to Korea's growth engine industry (KSIC $\leftrightarrow$ U.S SIC)

Weighted Edgelist format with reversed Weight

Classify node / node name size based on Betweenness centrality

Fig. 2 Data Processing Flowchart 
mediation in a whole network was high, the roles implemented for product-service convergence would also increase. For this, betweenness centrality has been commonly used in social network analysis.

In addition, graph data divided into two periods were overlapped, and new product and service nodes which appeared later were expressed in the MST with different colors. In this manner, the keywords excluded from the industry classification in the products and services marked in a different color (red in this study) were taken as the weak signal of convergence.

According to Hiltunen (2008), weak signals are rarely exposed topics, so we extracted low frequency keywords (small size nodes) from links connected to the network.

This study also used 'R program' in most data analysis projects.

\section{Results}

The U.S SIC is a 4-digit code allocated to companies by the US government to identify their business. This code is arranged in 11 sectors, and it is divided into 83 2-digit major groups and 416 3-digit industrial groups. It is comprised of a total of 1005 4digit industries.

Appendix 1 reveals that Korea's growth engine industry is mapped to 9 major groups $(28,35,36,37,38,48,49,73$ and 87) among the 83 2-digit major groups of SIC. The number of global listed companies by year of establishment in Appendix 2 represents the number of global listed companies $(16,151)$ on the 1 st digit of the U.S SIC. Table 2 below sates the number of global listed companies in the 2-digit major groups mapped to Korea's growth engine industries by year.

Table 3 below describes the services of the 2-digit major groups mapped to growth engine industries.

The same first digit in the SIC means same an industrial division. Therefore, 9 major groups can be grouped into five major classes (28, 35-38, 48-49, 73 and 87). Figure 3 below reveals the percentages of the five major groups in the same division for the past 11 years.

Table 2 Number of Global Listed Companies by Year of Establishment

\begin{tabular}{lllllllllllll}
\hline USSIC & 2005 & 2006 & 2007 & 2008 & 2009 & 2010 & 2011 & 2012 & 2013 & 2014 & 2015 & Total \\
\hline 28 & 140 & 136 & 143 & 76 & 80 & 76 & 62 & 47 & 36 & 47 & 26 & 869 \\
35 & 71 & 73 & 53 & 41 & 34 & 41 & 36 & 14 & 19 & 19 & 10 & 411 \\
36 & 116 & 141 & 112 & 77 & 65 & 74 & 56 & 35 & 28 & 30 & 17 & 751 \\
37 & 31 & 23 & 28 & 19 & 8 & 23 & 15 & 8 & 12 & 12 & 8 & 187 \\
38 & 39 & 65 & 45 & 42 & 19 & 28 & 16 & 20 & 18 & 25 & 14 & 331 \\
48 & 65 & 61 & 56 & 35 & 28 & 32 & 26 & 19 & 13 & 23 & 8 & 366 \\
49 & 77 & 67 & 66 & 29 & 28 & 42 & 26 & 16 & 16 & 23 & 10 & 400 \\
73 & 236 & 241 & 224 & 143 & 133 & 182 & 150 & 99 & 92 & 116 & 59 & 1675 \\
87 & 72 & 92 & 87 & 69 & 51 & 54 & 59 & 42 & 55 & 36 & 19 & 636 \\
Total & 847 & 899 & 814 & 531 & 446 & 552 & 446 & 300 & 289 & 331 & 171 & 5626 \\
\hline
\end{tabular}


Table 3 U.S SIC Major Group Mapped to Korea's Growth Engine Industries

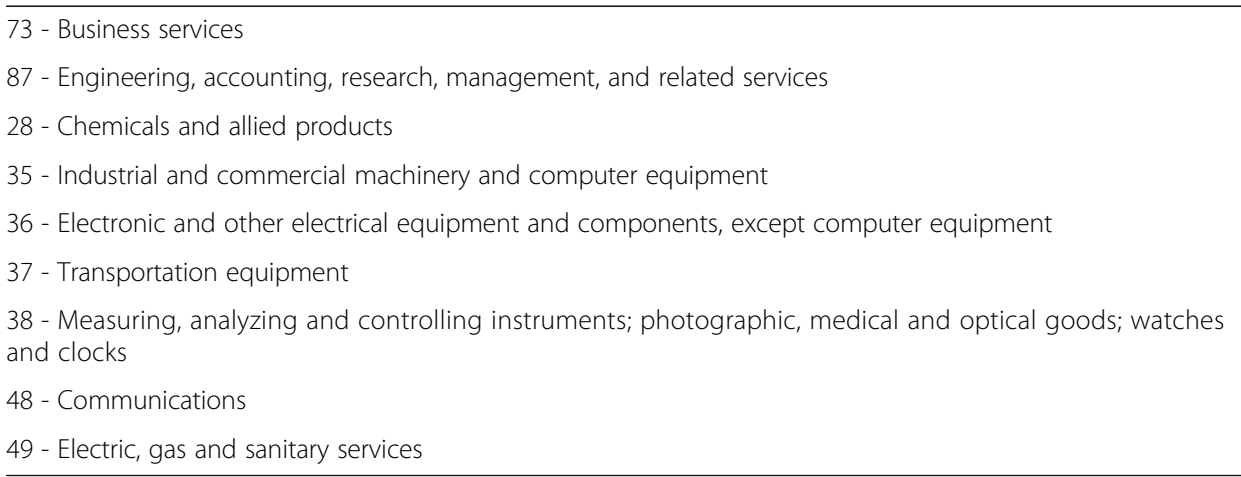

The five groups mapped to growth engine industries accounted for more than $50 \%$ in the same industrial division. In particular, the number of companies in Group 73 stayed over $70 \%$ for the past 11 years. In terms of the number of global listed companies, Group 73 is the highest among the total major groups.

\section{1. Products and services of the SIC 28 major group}

Major Group 28 is a group of chemicals and allied products. This major group includes establishments producing basic chemicals, and establishments manufacturing products by predominantly chemical processes. Establishments classified in this major group manufacture three general classes of products: (1) basic chemicals, such as acids, alkalies, salts, and organic chemicals; (2) chemical products to be used in further manufacture, such as synthetic fibers, plastics materials, dry colors, and pigments; and (3) finished chemical products to be used for ultimate consumption, such as drugs, cosmetics, and soaps; or to be used as materials or supplies in other industries, such as paints, fertilizers, and explosives.

From 2005 to 2010, chemicals, chemical products and pharmaceuticals were the mainstream. However, they shifted to cure, drugs, pharmaceuticals and healthcare products during 2011-2015.

The Weak signal appears as the smallest node in the connection line of the keyword network, and we extracted keyword that does not belong to the same industry to detect weak signals of convergence with other industries.

The product keywords under a weak signal included own healthcare product, medical device, cancer treatment, complementary product candidate, rare disease and commercial technology.

This can be interpreted as a signal that the chemical industry is converging with the healthcare and medical equipment industries as well as the medical and pharmaceutical industries Fig. 4.

\section{Products and services of the SIC 73 major group}

The Major Group 73 is a business services group based on ICT. This major group includes establishments primarily engaged in rendering services, not elsewhere 


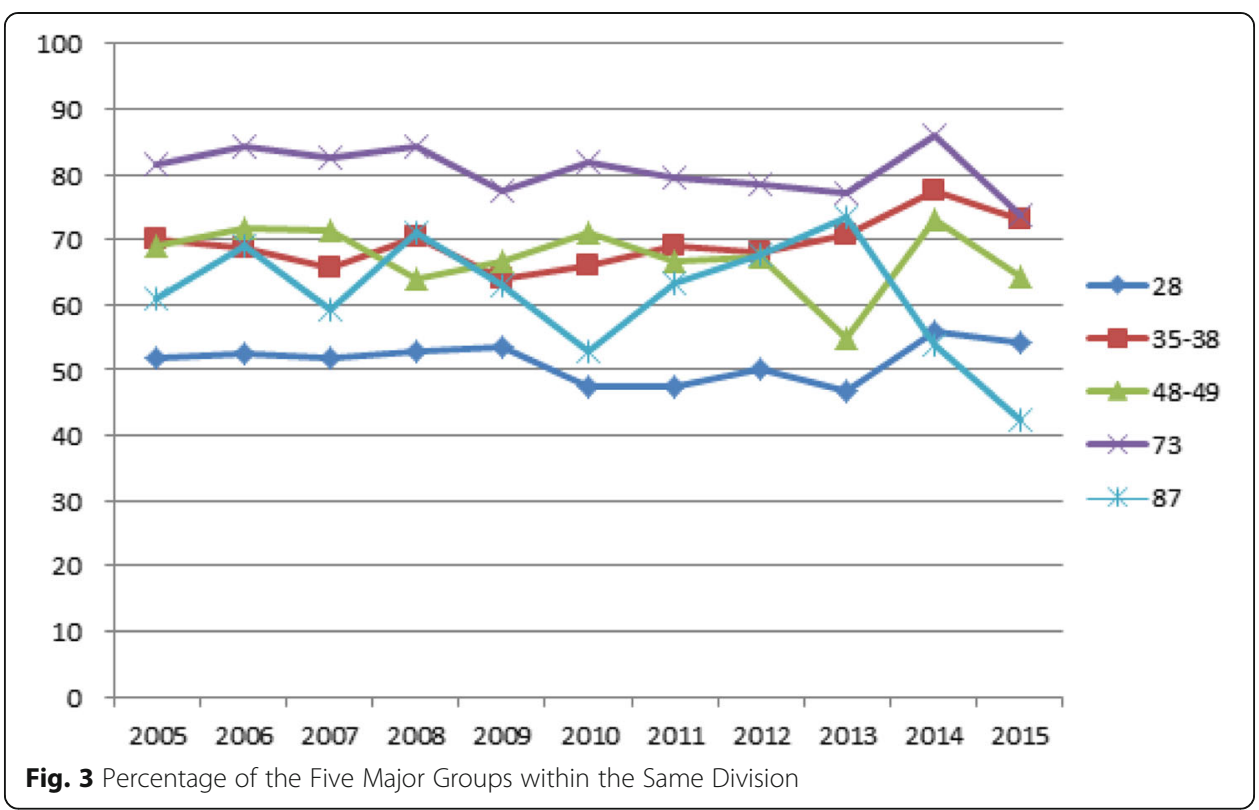

classified, to business establishments on a contract or fee basis, such as advertising, credit reporting, collection of claims, mailing, reproduction, stenographic, news syndicates, computer programming, photocopying, duplicating, data processing, services to buildings, and help supply services.

According to analysis results, this major group has continuously provided diverse services (e.g., information technology, investment \& financial management, finance, business support, etc.) for the past 11 years. From 2005 to 2010, computer system, hardware, web services, online ads, mobile phone, business support, Internet platform and consulting were primary services. During 2011-2015, investment services were further accelerated. Then, service configuration shifted to applied software, portal services, client-oriented, voice, brand, smartphone, ecommerce platform, information protection \& security solution, cloud software,

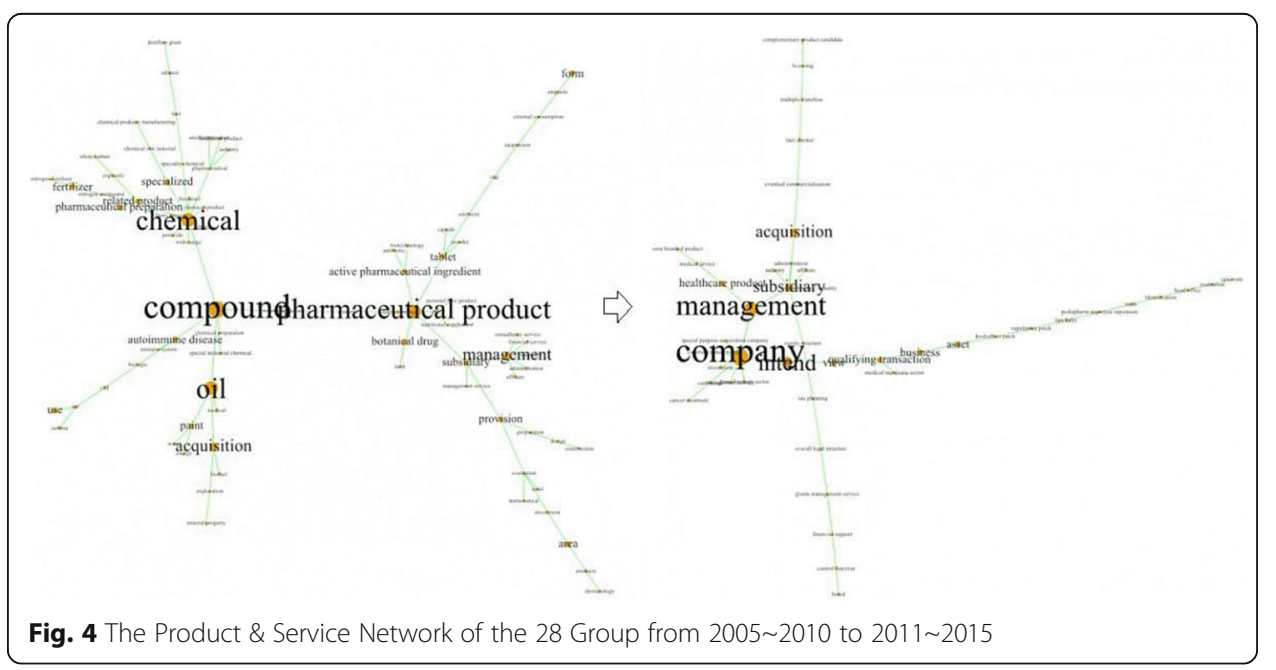




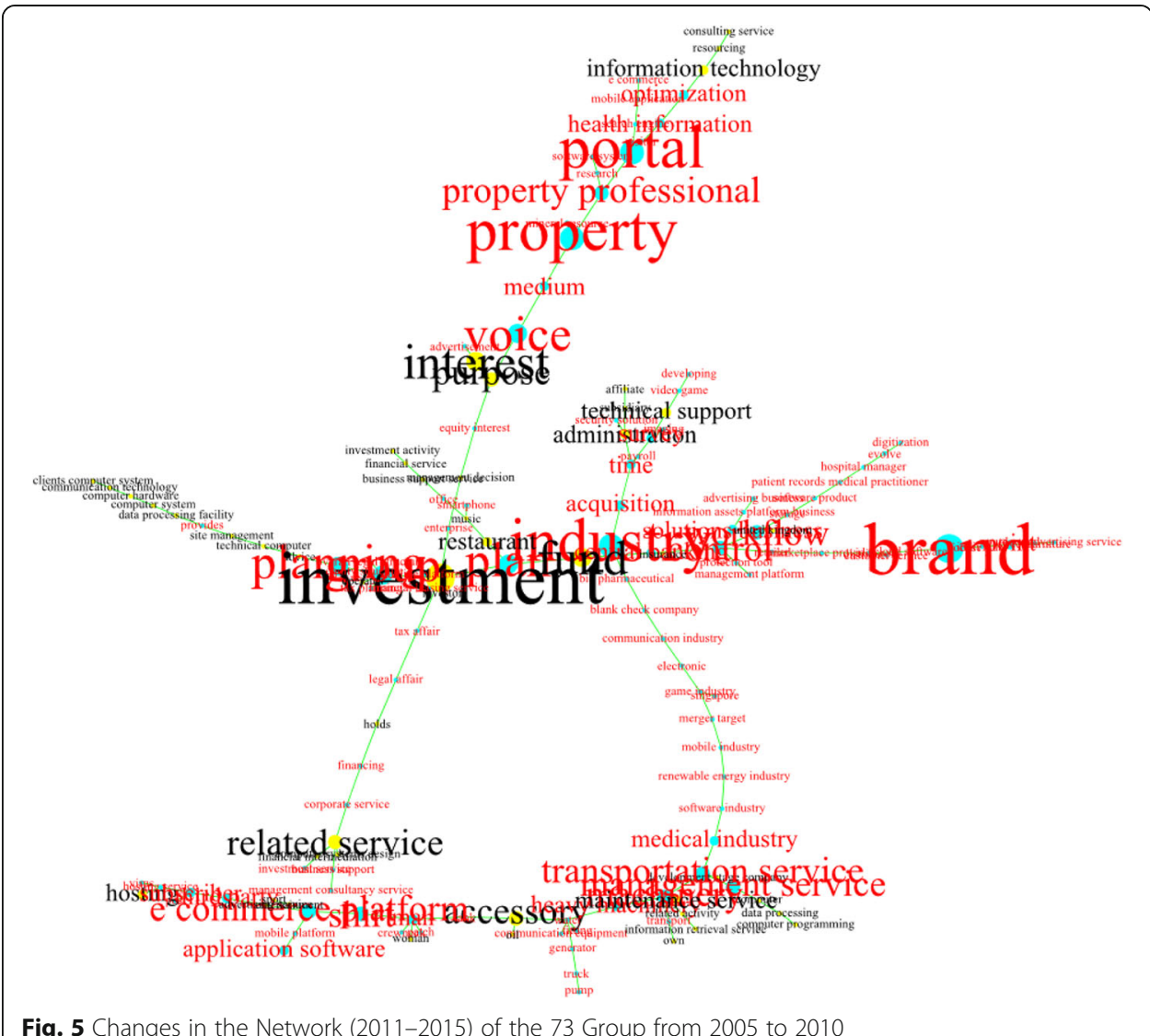

transportation and property services. In addition, centrality has expanded in health-related services Fig. 5.

What matters is that compared to the past in which particular services were specified, service keywords relating to diverse industries (e.g., medicine, game, communication, mobile, renewable energy) have emerged. The words under a weak signal include patient records, bio pharmaceutical, hospital manager, imaging, restaurant, tank, entertainment, water, mineral resource and blank check.

This can be interpreted as a signal that ICT industry is converging not only in medicine, bio, health, energy, transportation industry but also in entertainment, finance, defense, food industry etc. and can be seen that ICT industry is the main industrial field in the Fourth industrial revolution.

\section{Products and services of the SIC 35-38 major groups}

In Major Groups 35-38, the number of global listed companies in each group is small, and they belong to the same manufacturing division. Therefore, all service keywords were analyzed together. Major Groups 35-38 are related with machine and equipment. They are manufacturing industry-based groups which include the parts and products relating to industrial machine, transportation equipment, computer and measuring \& analysis instruments. 


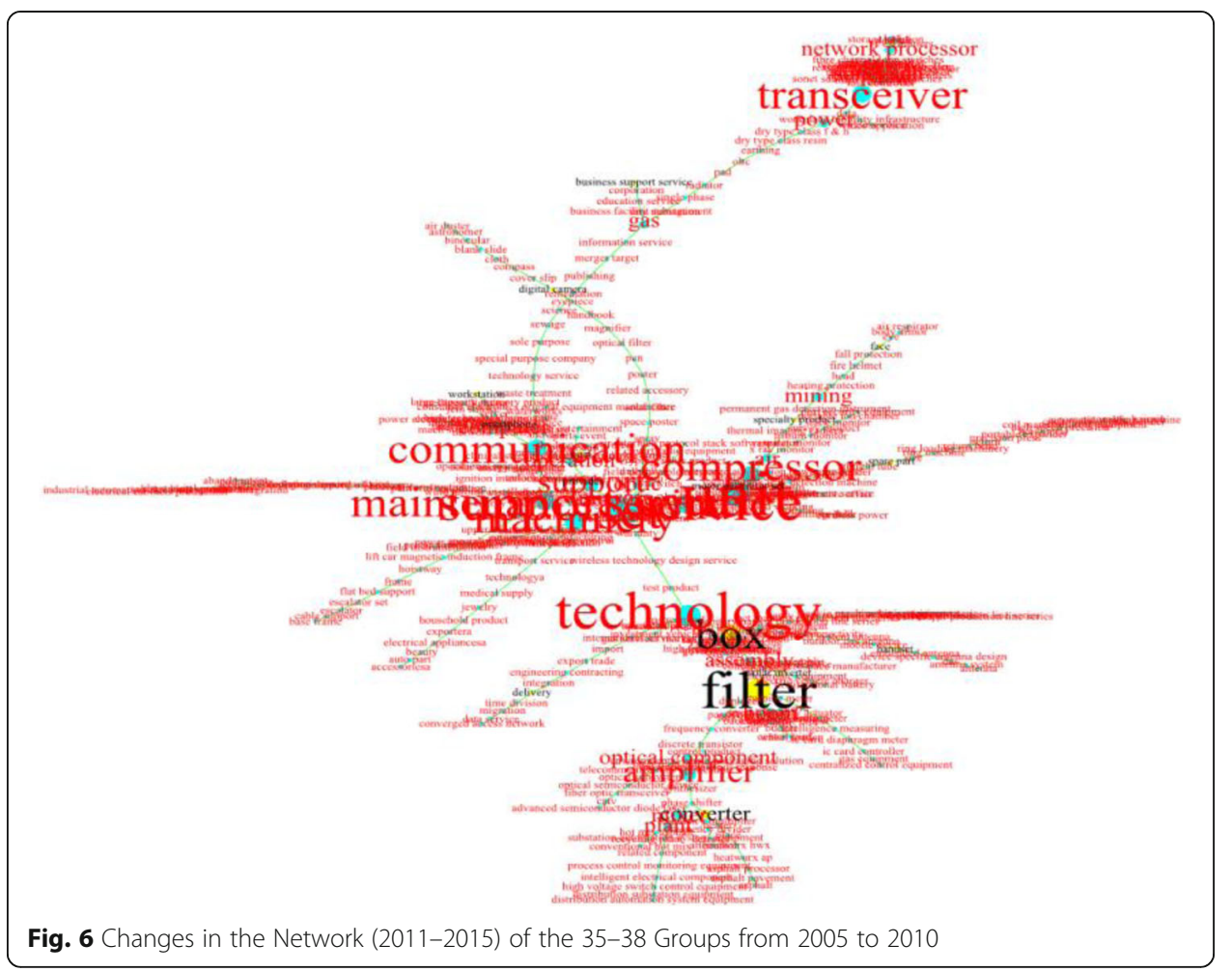

In terms of product configuration from 2005 to 2010, machine parts (e.g., generator, display, assembly, wheel, lamp, motor, panel, power supply, USB, lense, corgresistor, fixture, converter, etc.) accounted for a great portion. From 2011 to 2015, there was a shift to technology-oriented services including diverse machine. Product composition includes communication service, transceiver, network processor, amplifier, compressor, optical component, mining and maintenance service. Just like Group 73, investment and corporate management support services were further accelerated. The words under a weak signal include voice, water, gas, medical device, security, software solution, education and smart home. This can be interpreted as a signal that the mechanical and manufacturing industries are converging with medical equipment, security, education, smart home and environmental industries Fig. 6.

\section{Products and services of the SIC 48-49 major groups}

Major group 48 includes establishments furnishing point-to-point communications services, whether intended to be received aurally or visually; and radio and television broadcasting. This major group also includes establishments primarily engaged in providing paging and beeper services and those engaged in leasing telephone lines or other methods of telephone transmission, such as optical fiber lines and microwave or satellite facilities, and reselling the use of such methods to others.

The major services from 2005 to 2010 were telecommunication, radio, television, broadcasting, the Internet, motion picture and equipment. They shifted to channel, 


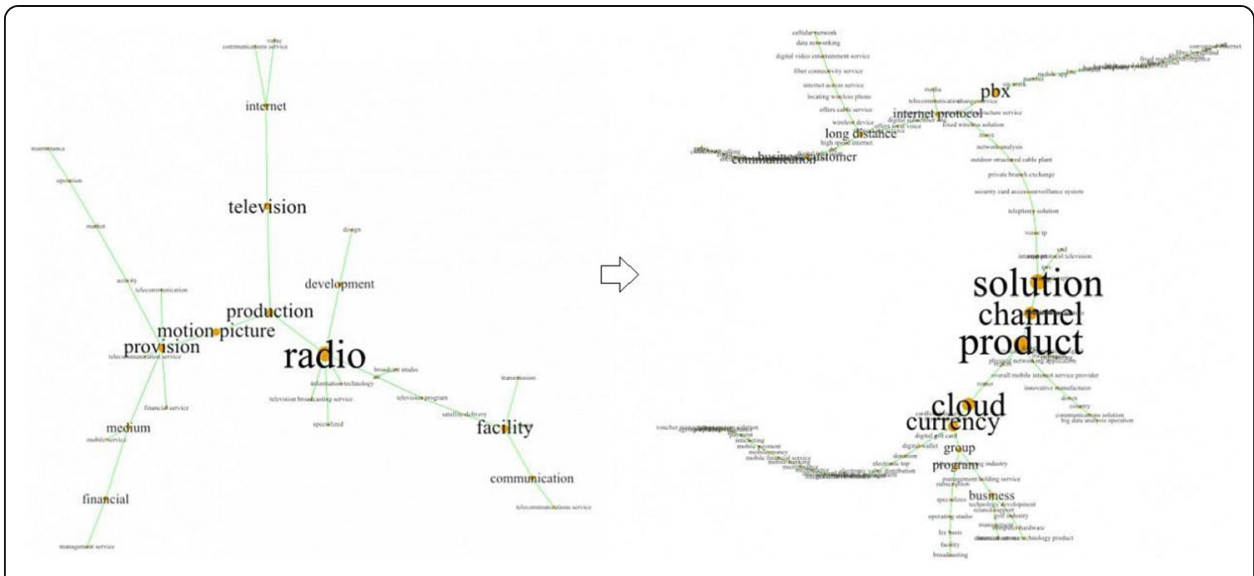

Fig. 7 The Product \& Service Network of the 48 Group from 2005 to 2010 to 2011-2015

broadband, pbx, high-speed internet, cloud and currency (digital wallet, digital gift card) during 2011-2015. The words under a weak signal converged with other industries include big data analysis, innovative manufacturer, mobile payment/banking, local voice, fixed wireless, digital video entertainment, security card access and surveillance system.

This can be interpreted as a signal that the telecommunication industry is converging with big data, mobile, security and entertainment industries Fig. 7.

Major Group 49 represents the field of electric, gas and sanitary services. This major group includes establishments engaged in the generation, transmission, and/or distribution of electricity or gas or steam. Such establishments may be combinations of any of the above three services and also include other types of services, such as transportation, communications, and refrigeration. Water and irrigation systems, and sanitary systems engaged in the collection and disposal of garbage, sewage, and other wastes by means of destroying or processing materials are also included.

The major services from 2005 to 2010 were generation facility, electric power \& energy, gas, oil, biomass, distribution system and transportation. During 2011-2015,

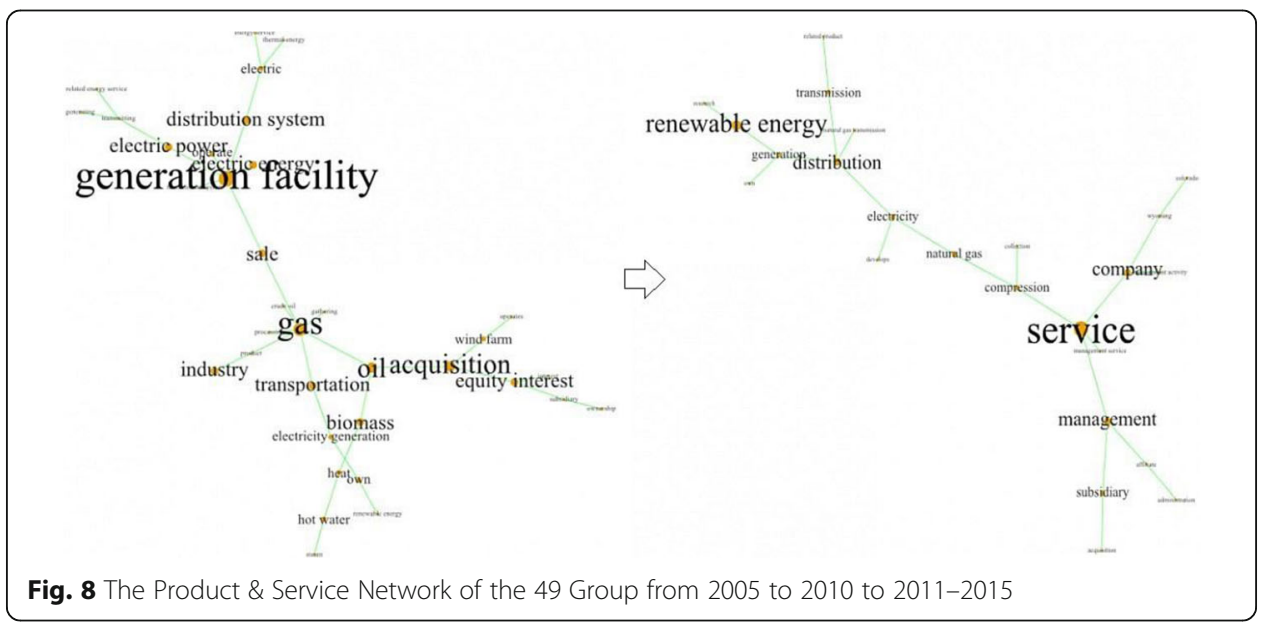


almost sale services were provided, but centrality expanded in services and renewable energy Fig. 8.

\section{Products and services of the SIC 87 major group}

Major Group 87 represents engineering, accounting, research, management, and related services. This major group includes establishments primarily engaged in providing engineering, architectural, and surveying services; accounting, auditing, and bookkeeping services; research, development, and testing services; and management and public relations services.

The major service keywords from 2005 to 2010 were consulting services relating to business management activities and investments and pharmaceutical products (e.g., disease, cancer, treatment, drug, reagent, etc.). In terms of changes in service keywords during 2011-2015, keyword centrality in marketing, strategy, administration and construction as well as pharmaceutical products (e.g., disease, treatment, etc.) further expanded. As a weak signal of convergence with other industries, the following words were found: single family housing unit, cultivation urban landscaping conservation, renovation, service industry, market governance garden and building energy conservation.

This can be interpreted as a signal that the engineering industry is converging with the construction, energy, and service industries Fig. 9.

\section{Conclusion and future work}

This study analyzed Korea's growth engine industries with the products and services of global listed companies which have been established for the past 11 years (2005-2015). These global listed companies represent growing businesses, and products and services are an indicators which represents the related industries. In addition, Korea's growth engine industry is the hottest industrial sector which should be strategically developed. Therefore, the study results have great implications. To examine the weak signal of inter-industry convergence, the keywords relating to the products and services from other industries were derived. The

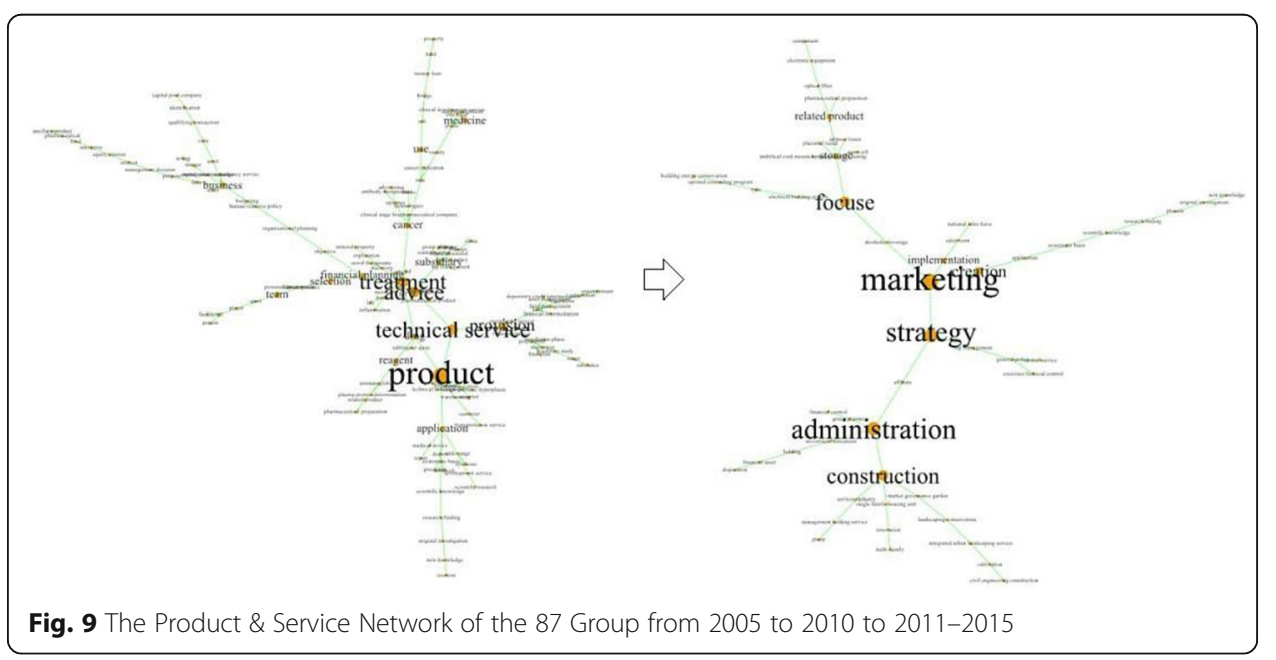


results of the analysis on the U.S SIC's five major groups mapped to Korea's growth engine industries found the followings:

Major Group 73 is a group which is most converged with diverse industries such as medicine, energy and communication. The keywords under the weak signal for the convergence also varied from diverse fields including bio-health, entertainment, environment and finance. In Major Group 28 as well, changes from chemical products to more specified products such as drugs and healthrelated products were found. Under a manufacture-based business type, Major Groups 35-38 shifted from machine, equipment and parts services to technologyoriented services. The weak signal of convergence such as education, smart home, environment, medicine and security services occurred. Major Groups 48 and 49 also found a weak signal such as big data analysis, mobile payment/banking, security card and renewable energy, slightly different from industry services. In Major Group 87 as well, there was a shift from traditional consulting services to marketing and strategy services which reflect trends (e.g., single family, service industry, building energy).

This study showed the possibility of detecting weak signals of industrial convergence to prepare for the Fourth industrial revolution era by using product and service information of global listed companies. The proposed method is advantageous in that it can detect weak signals more efficiently than time-consuming and expensive expert methods.

In this study, five major groups were grouped and analyzed every 5 years. Therefore, there should be a more specific analysis on Major Group 73 in which convergence with diverse industries has occurred. In addition, it is necessary to analyze connectivity with technology trends by analyzing patents and papers and examine the products and service trends of global listed companies in 11 industrial divisions.

The limitation of this study is that only the information of products and services of listed companies is used to detect weak signals of industrial convergence. The proposed methodology should be applied not only to BM patent information including new business model information but also to information on products and services of unlisted companies. In addition, since the study has been limited to the fields of the growth engine industry being promoted in Korea, future research needs to be studied in the whole industry field. For more accurate analysis, however, it appears that there should be a Delphi survey which acquires opinions from expert groups based on the study results.

This study is expected to provide businesses a hint for the development of products and services by recognizing the weak signal of convergence with other industries in addition to service trends. Furthermore, global listed companies' analysis results would be useful in analyzing business environments for predicting and being prepared for the future.

\section{Endnotes}

${ }^{1}$ 1. Wearables in the enterprise, 2. Consumer IoT and 'smart home', 3. Consumer privacy protection, 4. Counterterrorism technologies, 5. Cybersecurity services to protect enterprises, 6. Financial tech in emerging markets, 7. Digital health and Big Data, 8. The 'Uberization' of manufacturing, 9. Autonomous cars, 10. Space exploration. 


\section{Appendix 1}

Table 4 US SIC Code and KSIC Mapping of Growth Engine

\begin{tabular}{|c|c|c|c|}
\hline Growth Engine & $\begin{array}{l}\text { U.S SIC } \\
\text { Code }\end{array}$ & $\mathrm{KSIC}$ & Business Type \\
\hline \multirow[t]{6}{*}{ Smart car } & 3812 & 27211 & $\begin{array}{l}\text { Manufacture of wireless navigation devices and } \\
\text { measuring instruments }\end{array}$ \\
\hline & 3663 & 26429 & Other wireless communication equipment manufacturing \\
\hline & 3711 & 30121 & Car and other passenger vehicle manufacturing \\
\hline & $\begin{array}{l}\text { No } \\
\text { Mapping }\end{array}$ & 30320 & Automobile body parts manufacturing \\
\hline & $\begin{array}{l}\text { No } \\
\text { Mapping }\end{array}$ & 30392 & Automobile electric system manufacturing \\
\hline & 3714 & 30399 & Other auto parts manufacturing \\
\hline \multirow[t]{4}{*}{ 5G mobile communication } & 3663 & 26429 & Other wireless communication equipment manufacturing \\
\hline & 7372 & 58222 & Development \& supply of application software \\
\hline & $\begin{array}{l}\text { No } \\
\text { Mapping }\end{array}$ & 61220 & Wireless communication \\
\hline & 4899 & 61299 & Other electric communication \\
\hline \multirow{4}{*}{$\begin{array}{l}\text { Deep-sea / extreme-environment } \\
\text { offshore plant }\end{array}$} & 3561 & 29131 & Liquid pump manufacturing \\
\hline & 3731 & 31119 & Other vessel manufacturing \\
\hline & $\begin{array}{l}\text { No } \\
\text { Mapping }\end{array}$ & 42136 & Underwater construction \\
\hline & 8711 & 72129 & Other engineering services \\
\hline $\begin{array}{l}\text { High-speed vertical take-off \& } \\
\text { landing unmanned aerial vehicle }\end{array}$ & 3721 & 31310 & Aircraft, spacecraft and auxiliary system manufacturing \\
\hline Intelligent robot & $\begin{array}{l}\text { No } \\
\text { Mapping }\end{array}$ & 29280 & Industrial robot manufacturing \\
\hline \multirow[t]{4}{*}{ Wearable smart device } & 3661 & 26422 & Mobile phone manufacturing \\
\hline & 3663 & 26429 & Other wireless communication equipment manufacturing \\
\hline & 3845 & 27112 & Electric diagnosis \& treatment system manufacturing \\
\hline & 7372 & 58221 & Development \& supply of system software \\
\hline \multirow[t]{4}{*}{ Tangible contents } & 7372 & 58222 & Development and supply of application software \\
\hline & $\begin{array}{l}\text { No } \\
\text { Mapping }\end{array}$ & 59114 & Production of broadcasting programs \\
\hline & $\begin{array}{l}\text { No } \\
\text { Mapping }\end{array}$ & 70121 & Electrical \& electronic engineering $R \& D$ \\
\hline & $\begin{array}{l}\text { No } \\
\text { Mapping }\end{array}$ & 63991 & Supply of database and online information \\
\hline \multirow[t]{6}{*}{ Smart bio-production system } & 3822 & 27215 & Automatic measurement \& control system manufacturing \\
\hline & 3823 & 27216 & Manufacture of industrial process control equipment \\
\hline & $\begin{array}{l}\text { No } \\
\text { Mapping }\end{array}$ & 27112 & Electric diagnosis \& treatment system manufacturing \\
\hline & $\begin{array}{l}\text { No } \\
\text { Mapping }\end{array}$ & 27213 & $\begin{array}{l}\text { Manufacturing of inspection, measurement and analysis } \\
\text { equipment }\end{array}$ \\
\hline & 3829 & 27219 & $\begin{array}{l}\text { Manufacture of other measuring, testing, navigation, } \\
\text { control and precision equipment }\end{array}$ \\
\hline & 7372 & 58222 & Development and supply of application software \\
\hline \multirow[t]{2}{*}{ Virtual training system } & 7371 & 62010 & Computer programming service \\
\hline & 3721 & 31310 & Aircraft, spacecraft and auxiliary system manufacturing \\
\hline Customized wellness care & 7372 & 58222 & Development and supply of application software \\
\hline
\end{tabular}


Table 4 US SIC Code and KSIC Mapping of Growth Engine (Continued)

\begin{tabular}{|c|c|c|c|}
\hline Growth Engine & $\begin{array}{l}\text { U.S SIC } \\
\text { Code }\end{array}$ & KSIC & Business Type \\
\hline & 7371 & 62010 & Computer programming service \\
\hline & 3845 & 27112 & Electric diagnosis \& treatment system manufacturing \\
\hline & 7379 & 62,090 & $\begin{array}{l}\text { Other information technology \& computer operation- } \\
\text { related service }\end{array}$ \\
\hline \multirow{6}{*}{$\begin{array}{l}\text { Smart public safety management } \\
\text { system }\end{array}$} & 3669 & 26410 & Wire communication equipment manufacturing \\
\hline & 3663 & 26429 & Other wireless communication equipment manufacturing \\
\hline & $\begin{array}{l}\text { No } \\
\text { Mapping }\end{array}$ & 61220 & Wireless communication \\
\hline & 7371 & 62010 & Computer programming service \\
\hline & 7373 & 62021 & $\begin{array}{l}\text { Computer system integration-targeted advisory \& con- } \\
\text { struction service }\end{array}$ \\
\hline & $\begin{array}{l}\text { No } \\
\text { Mapping }\end{array}$ & 63991 & Provision of database and online information \\
\hline \multirow{5}{*}{$\begin{array}{l}\text { Hybrid new \& renewable } \\
\text { energy system }\end{array}$} & 3621 & 28111 & Motor \& power generator manufacturing \\
\hline & 3677 & 28112 & Transformer manufacturing \\
\hline & $\begin{array}{l}\text { No } \\
\text { Mapping }\end{array}$ & 28202 & Battery manufacturing \\
\hline & 4931 & 35119 & Other power generation businesses \\
\hline & 7373 & 62021 & $\begin{array}{l}\text { Computer system integration-targeted advisory \& con- } \\
\text { struction service }\end{array}$ \\
\hline \multirow{3}{*}{$\begin{array}{l}\text { Direct-current transmission } \\
\& \text { distribution system }\end{array}$} & 3677 & 28112 & Transformer manufacturing \\
\hline & 3613 & 28121 & $\begin{array}{l}\text { Electric circuit switch and protection \& connection device } \\
\text { manufacturing }\end{array}$ \\
\hline & 3625 & 28122 & Switchboard and control panel manufacturing \\
\hline \multirow{3}{*}{$\begin{array}{l}\text { Supercritical } \mathrm{CO}_{2} \text { power } \\
\text { generation system }\end{array}$} & 3511 & 29119 & Other engine and turbine manufacturing \\
\hline & 3564 & 29176 & $\begin{array}{l}\text { Manufacture of distillation units, heat exchangers and gas } \\
\text { generators }\end{array}$ \\
\hline & 4931 & 35119 & Other power generation businesses \\
\hline \multirow[t]{3}{*}{ Intelligent semiconductor } & 3674 & 26110 & Electronic integrated circuit manufacturing \\
\hline & 7372 & 58222 & Development and supply of application software \\
\hline & 8731 & 70121 & Electrical \& electronic engineering R\&D \\
\hline \multirow[t]{5}{*}{ Convergence materials } & $\begin{array}{l}\text { No } \\
\text { Mapping }\end{array}$ & 20111 & Manufacture of basic petrochemicals \\
\hline & 2865 & 20119 & Manufacture of other basic organic chemicals \\
\hline & 2819 & 20129 & Manufacture of other basic inorganic chemicals \\
\hline & 2816 & 20131 & $\begin{array}{l}\text { Manufacture of inorganic pigment and other metal } \\
\text { oxides }\end{array}$ \\
\hline & 2821 & 20302 & Manufacture of synthetic resin and other plastic materials \\
\hline \multirow{3}{*}{$\begin{array}{l}\text { Intelligent Internet of Things } \\
\text { (IoT) }\end{array}$} & 7372 & 58222 & Development and supply of application software \\
\hline & $\begin{array}{l}\text { No } \\
\text { Mapping }\end{array}$ & 61220 & Wireless communication \\
\hline & 7379 & 62090 & $\begin{array}{l}\text { Other information technology \& computer operation- } \\
\text { related service }\end{array}$ \\
\hline \multirow[t]{4}{*}{ Big data } & 7372 & 58222 & Development and supply of application software \\
\hline & 7371 & 62010 & Computer programming service \\
\hline & 7379 & 62090 & $\begin{array}{l}\text { Other information technology \& computer operation- } \\
\text { related service }\end{array}$ \\
\hline & & 63991 & Supply of database and online information \\
\hline
\end{tabular}


Table 4 US SIC Code and KSIC Mapping of Growth Engine (Continued)

\begin{tabular}{llll}
\hline Growth Engine & U.S SIC & KSIC & Business Type \\
& Code & & \\
& No & & \\
& Mapping & & \\
Advanced material processing & No & 29176 & Manufacture of distillation units, heat exchangers and gas \\
system & Mapping & generators \\
& No & 29221 & Manufacture of electronically applied machine tools \\
& Mapping & & \\
& No & 29222 & Metal cutting machine manufacturing \\
& Mapping & & \\
& 3541 & 29223 & Metal forming machine manufacturing \\
& 3542 & 29229 & Other processing machine manufacturing \\
\hline
\end{tabular}

\section{Appendix 2}

Table 5 Number of global listed companies by year of establishment

\begin{tabular}{lllllllllllll}
\hline USSIC & 2005 & 2006 & 2007 & 2008 & 2009 & 2010 & 2011 & 2012 & 2013 & 2014 & 2015 & Total \\
\hline 0 & 32 & 17 & 39 & 22 & 14 & 32 & 28 & 6 & 9 & 8 & 3 & 210 \\
1 & 394 & 467 & 449 & 192 & 181 & 262 & 217 & 89 & 64 & 56 & 52 & 2424 \\
2 & 270 & 259 & 276 & 144 & 149 & 160 & 131 & 94 & 77 & 84 & 48 & 1694 \\
3 & 367 & 440 & 363 & 254 & 197 & 252 & 178 & 113 & 109 & 111 & 67 & 2454 \\
4 & 206 & 178 & 171 & 100 & 84 & 104 & 78 & 52 & 53 & 63 & 28 & 1121 \\
5 & 162 & 184 & 181 & 145 & 137 & 151 & 128 & 77 & 78 & 69 & 40 & 1357 \\
6 & 488 & 579 & 602 & 339 & 255 & 326 & 299 & 233 & 284 & 173 & 186 & 3770 \\
7 & 289 & 286 & 271 & 170 & 172 & 222 & 189 & 126 & 119 & 135 & 80 & 2066 \\
8 & 118 & 133 & 147 & 97 & 81 & 102 & 93 & 62 & 75 & 67 & 45 & 1028 \\
9 & 6 & 15 & 10 & 7 & 4 & 5 & 2 & 4 & 4 & 1 & 5 & 72 \\
Total & 2332 & 2558 & 2509 & 1470 & 1274 & 1616 & 1343 & 856 & 872 & 767 & 554 & 16,151 \\
\hline
\end{tabular}

\section{Appendix 3}

Table 6 Search Strategy of ORBIS (From 2005 to 2010)

\begin{tabular}{|c|c|c|c|}
\hline Product name & \multicolumn{3}{|l|}{ Orbis } \\
\hline Update number & 158 & & \\
\hline Software version & 129.00 & & \\
\hline Data update & $15 / 04 / 2017\left(n^{\circ} 15,804\right)$ & & \\
\hline \multirow[t]{2}{*}{ Export date } & 19/04/2017 & & \\
\hline & & Step result & Search result \\
\hline 1. & All companies & $201,609,707$ & $201,609,707$ \\
\hline 2. & Status: Active companies & $161,008,585$ & $161,008,585$ \\
\hline 3. & $\begin{array}{l}\text { Accounting template: Industrial companies, } \\
\text { Exclude branches }\end{array}$ & $105,935,764$ & $81,007,724$ \\
\hline 4. & $\begin{array}{l}\text { Year of incorporation: on and after } 2005 \text { up to } \\
\text { and including } 2010\end{array}$ & $37,882,576$ & $20,007,446$ \\
\hline 5. & $\begin{array}{l}\text { Listed/Unlisted companies: Publicly listed } \\
\text { companies, Formerly publicly listed companies }\end{array}$ & 102,807 & 11,883 \\
\hline & Boolean search: 1 And 2 And 3 And 4 And 5 & & \\
\hline & & TOTAL & 11,883 \\
\hline
\end{tabular}




\section{Acknowledgements}

This paper was designated that contribute to SOltmC 2017 conference goal,"Let us conquer the growth limits of capitalism through new combination between technology, and market or society". The main ideas in this paper were previously reported in the conference (Lee-Nam et al., 2017).

\section{Funding}

This research was supported by Korea Institute of Science and Technology Information(KISTI)

\section{Availability of data and materials}

All data can be obtained by manually querying the ORBIS system.

\section{Authors' contributions}

LNK, BRL, JHP, and YHM carried out a systematic literature review. LNK, BRL, YHS, and YKK collected data and programmed algorithms to analysis the data. LNK and YKK wrote and revised the final manuscript. All authors read and approved the final manuscript.

\section{Competing interests}

The authors declare that they have no competing interests.

\section{Publisher's Note}

Springer Nature remains neutral with regard to jurisdictional claims in published maps and institutional affiliations.

\section{Author details}

${ }^{1}$ Korea Institute of Science and Technology Information (KISTI), Seoul, Korea. ${ }^{2}$ Department Of Computer Science and Engineering, Chungnam National University, Seoul, Korea.

Received: 17 November 2017 Accepted: 17 January 2018

Published online: 27 March 2018

\section{References}

A Strategy for American Innovation: Securing Our Economic Growth and Prosperity (2011), The White House, https:// obamawhitehouse.archives.gov/sites/default/files/uploads/InnovationStrategy.pdf. Accessed 20 Aug 2016.

An Integrated Industrial Policy for the Globalization Era: Putting Competitiveness and Sustainability at Center Stage (2010), European Commission, https://www.kowi.de/Portaldata/2/Resources/fp7/2010-com-industrial-policy.pdf. Accessed 10 Sep 2016

Ansoff, I. H. (1975). Managing strategic surprise by response to weak signals. California Management Review, 18(2), 21-33.

Brown, D. (2007). Horizon scanning and the business environment: The implications for risk management. BT Technology Journal, 25(1), 208-214.

Coffman, B. S. (1997), Weak Signal Research: Part I-V, MG Taylor Corporation. Louisville, KT, USA.

Cormen, T.H. et al. (2001), Introduction to Algorithms - Second Edition, The MIT Press. Cambridge, Massachusetts London, England.

Curran, C. S., \& Leker, J. (2011). Patent indicators for monitoring convergence - Examples from NFF and ICT. Technological Forecasting and Social Change, 78, 256-273.

Godet, M., (1994), From Anticipation to Action, A Handbook of Strategic Prospective, UNESCO Publishing. France. Hiltunen, E. (2008): The Future Sign and Its Three Dimensions, Futures, 40(3), 247-260.

Industrial Structure Vision 2010 (2010), Ministry of Economy, Trade and Industry, http://www.meti.go.jp/english/policy/ economy/industrial.html. Accessed 10 Oct 2016

Janghyeok, Y. (2012). Detecting weak signals for long-term business opportunities using text mining of web news. Expert Systems with Applications, 39, 12543-12550.

JinHyo, J. Y., DongKyu, W., EuiSeob, J., KyungBae, P., JeongHo, Y., \& JiYoung, P. (2016). The relationship between technology, business model, and market in autonomous car and intelligent robot industries. Technological Forecasting and Social Change, 103, 142-155.

Kaivo-oja, J. (2012). Weak signals analysis, knowledge management theory and systemic socio-cultural transitions. Futures, 44, 206-217.

Kuosa, T. (2010). Futures signals sense-making framework (FSSF): A start-up tool to analyse and categorise weak signals, wild cards, drivers, trends and other types of information. Futures, 42(1), 42-48.

Law, J., \& Whittaker, J. (1992). Mapping acidification research: A test of the co-word method. Scientometrics, 23, 417-461.

Lee-Nam, K., Bang-Rae, L., Jun-Hwan, P., Yeong-Ho, M. \& Young-Kuk, K. (2017), Trend Analysis using Information of Products and Services of Global Listed Companies - Focusing on Growth Engine Industry in Korea -, SOltmC 2017, Latvia.

Lee-Nam, K., Jun-Hwan, P., Yeong-Ho, M., \& Bang-Rae, L. (2016). An analysis of growth engine industries in the ORBIS DB. Asian Journal of Innovation and Policy, 5(3), 275-292.

Maha, M. Y. (2016). Innovation capability and its role in enhancing the relationship between TQM practices and innovation performance. Journal of Open Innovation: Technology, Market, and Complexity, 2(6).

Newman, M. E. J., \& Girvan, M. (2004). Finding and evaluating community structure in networks. Physical Review. E, Statistical, Nonlinear, and Soft Matter Physics, 69, 026113.

Sandro, M., Gustavo, C., \& Joao, C. (2012). The strategic strength of weak signal analysis. Futures, 44, 218-228.

Schnaars, S., Thomas, G., \& Irmak, C. (2008). Predicting the emergence of innovations from technological convergence: Lessons from the twentieth century. Journal of Macromarketing, 28(2), 157-168.

Scott, J. (1991). Social network analysis: A handbook. London: SAGE Publications Inc.

Seok-in, J., et al. (2014). Assessment of Korea's growth engine policies and future challenges. KIET Research Report, 723. 
Sun-Hi, Y., et al. (2009). A study on the search for weak signal of technological innovation using quantitative information analysis. Technology Innovation Research, 17(2).

Svirina, A., Zabbarova, A., \& Oganisjana, K. (2016). Implementing open innovation concept in social business. Journal of Open Innovation: Technology, Market, and Complexity, 2(20).

Tabatabaei, N. (2011), Detecting Weak Signals by Internet-Based Environmental Scanning, University of Waterloo. Waterloo, Ontario, Canada.

The 10 Biggest Startup Opportunities in 2016,ClO Magazine, http://www.cio.com/article/3019718/startups/the-10biggest-startup-opportunities-in-2016.html. Accessed 20 Jan 2016.

Thorleuchter, D., \& Van den Poel, D. (2015). Idea mining for web-based weak signal detection. Futures, 66, 25-34.

Trajtenberg, M., Rebecca, H., \& Adam, J. (1997). University versus corporate patents: A window on the basicness of invention. Economics of Innovation and New Technology, 5, 19-50.

Submit your manuscript to a SpringerOpen ${ }^{\circ}$ journal and benefit from:

- Convenient online submission

- Rigorous peer review

- Open access: articles freely available online

- High visibility within the field

- Retaining the copyright to your article

Submit your next manuscript at $>$ springeropen.com 